\title{
特集 細胞内膜系の諸相
}

\section{核と Ca シグナル}

\section{川 野 誠 子}

\section{$\mathrm{Ca}^{2+}$ Signaling In The Cell Nucleus}

\section{Seiko Kawano}

Department of Cardiovascular Diseases, Medical Research Institute, Tokyo Medical and Dental University, 1-5-45 Yushima, Bunkyo-ku, Tokyo, 113-8519, Japan

$\mathrm{Ca}^{2+}$ signals in the nucleus play important roles in various functions, such as gene transcription, protein transport, appoptosis, and diseased states. It has long been accepted that $\mathrm{Ca}^{2+}$ freely flows by diffusion through nuclear pore complex (NPC) between cytosol and nucleus. Recently, however, there are several evidences to support the existence of the independent regulation of nuclear $\mathrm{Ca}^{2+}$. The presence of $\mathrm{Ca}^{2+}$ signaling molecules in nuclear envelope (NE), Ca-ATPase $\mathrm{Ca}^{2+}$ pump, $\mathrm{IP}_{3}$ receptor, $\mathrm{IP}_{4}$ receptor and ryanodine receptor, and the existence of nucleo-cytoplasmic $\mathrm{Ca}^{2+}$ gradients are identified. It is indicated that nuclear envelope may serve as a barrier to cytosolic $\mathrm{Ca}^{2+}$ changes and function as the $\mathrm{Ca}^{2+}$ store to sustain the propagation of $\mathrm{Ca}^{2+}$ signals through the nucleoplasm. In this paper, I would like to introduce the recent studies about $\mathrm{Ca}^{2+}$ transporting systems of the $\mathrm{NE}$, cross-talk between cytosolic and nuclear $\mathrm{Ca}^{2+}$ pools, and the regulation of NPC.

Key words : nucleus $/$ Nuclear envelope $/ \mathrm{Ca}^{2+}$ signals $/ \mathrm{Ca}^{2+}$ store

\section{1.はじめに}

近年 $\mathrm{Ca}$ シグナルの研究は著しく進展し, 細胞 内 $\mathrm{Ca}$ のシグナル伝達系に関しては，その基本的 なメカニズムの多くが解明されてはじめてい る $^{1.2)}$. そして今, 新たに細胞の核の $\mathrm{Ca}$ シグナ ルが注目されてきた。核の機能のうち(1)遺伝子転 写, (2)蛋白質輸送, (3)アポトーシスの3つのプロ セスには Ca シグナルが深く関与していることが
知られている. 従って, 核の $\mathrm{Ca}$ シグナルとその 核内での調節機構の詳細な解明は，これら核の機 能を理解する上で, 非常に重要であると考えられ る. 最近, 核の $\mathrm{Ca}$ 供給システムとして, 従来の 「核膜孔複合体 nuclear pore complex (NPC) の中央の大きな孔を介して, 細胞質の $\mathrm{Ca}$ が自由 に核内に拡散していく」という考え方に対して, 矛盾する事実が少しずっ明らかとなり，NPCを 介する核 $\mathrm{Ca}$ の供給に疑問が投げかけられるよう 


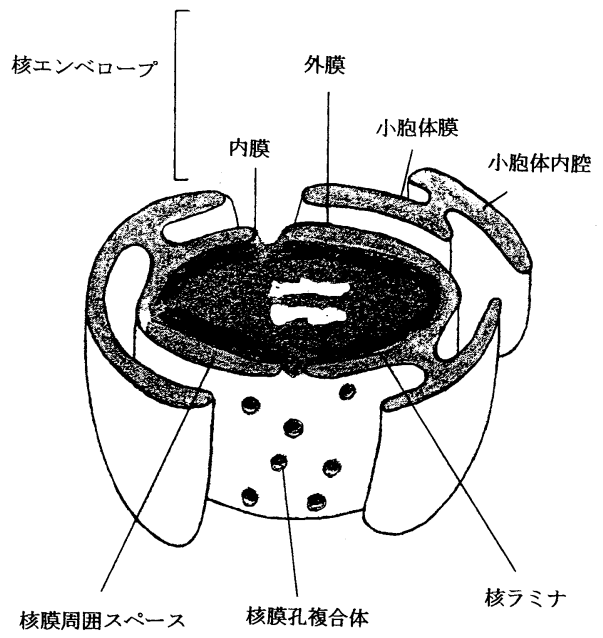

Fig. 1 Structure of Nuclear Envelope 核エンベロープは外膜, 内膜より構成され, 外膜は 小胞体 (ER)へつながっている. (Molecular biology of The Cell ๖り)

になってきた，本稿ではこの核の $\mathrm{Ca}$ の輸送シス

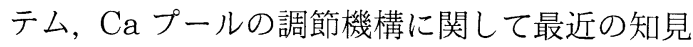
を考察する.

\section{2. 核膜の構造と機能}

核は細胞内で核膜によって細胞質と隔絶されい るが，その構造は通常の膜と異なり内膜と外膜の 二重膜から構成されている。 そして両膜の間には 核周囲スペースが形成され，核全体を包み，核工 ンベロープ (Nuclear Envelope : NE) と呼ばれ る. 核の外膜は, 小胞体膜と連続的に繫がってお り, 近年の研究で核周囲スペースは小胞体 (ER) の内腔と連続して交通し，小胞体と同様に $\mathrm{Ca}$ ス トアーとしての役割を果たしていることが分って きた. 内膜と外膜は核膜孔複合体 (NPC) の部分 で周期的に融合している (Fig. 1) ${ }^{3)}$. 核膜孔複合 体は約 $120 \mathrm{kD}$ の円柱状の構造を持つ蛋白質複合 体であり，電子顕微鏡による観察ではその中央に は約 $10 \mathrm{nM}$ の直径 $100 \mathrm{nM}$ の長さのチャネルを 有していることが示された ${ }^{4)}$. 従来はこの NPC の孔を介して, RNA 等の核内物質や, 細胞質の 蛋白質等の輸送が行われていると考えられ，40
$\mathrm{kD}$ 以下の小物質や種々のイオンはこの NPC の 孔を受動的に，自由に拡散によって移動している と考えられてきた.しかし，近年の研究では， NPC は単なる孔ではなくイオンチャネル様の機 能を持つこと，そして，核エンベロープには種々 のイオンチャネルやトランスポーターが存在する ことが明らかにされ，それらはセカンドメッセン ジャーにより細胞質および核内から調節を受け活 性化, 不活性化が起こっている可能性が指摘され てきた. 従って, 核内之細胞質間との物質輸送シ ステムは単に NPC のみでなく, 核エンベロープ が重要な役割を果たしていることが推測され，こ れらを解明する研究が現在脚光を浴びつつある.

\section{3. 核と Ca シグナル}

\section{1 核エンベロープに存在する $\mathrm{Ca}$ シグナル} 分子

核内 $\mathrm{Ca}$ の自動制御説に対して最初に異論が出た のは, 核膜に Ca ポンプ (nuclear Ca-ATPase : NCA) が存在することが分かってからである ${ }^{5)}$. 1989 年にはこの存在が確認され ${ }^{6)}$, 最近になっ て NCA は核の外膜に位置していることも分って

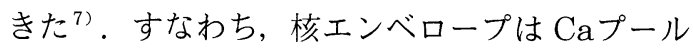
としての役割を持っていることが確認されたこと になる.この事は, 自動制御に対する 1 つの確固た る反論となっている. そして, 近年になって Ca signaling molecules の Receptors として inositol 1,4,5-tris-phosphate receptors $\left(\mathrm{IP}_{3} \mathrm{R}\right)^{8)}$ や inositol 1,3,4,5-tetrakisphosphate $\left(\mathrm{IP}_{4} \mathrm{R}\right)$ 等が核膜に存在することが相次いで分ってきた. さらに 1996 年には $\mathrm{IP}_{3} \mathrm{R}$ とリアノジン受容体 (RYR) が核エンベロープの内膜に存在すること が示され ${ }^{9)}$, また免疫電子顕微鏡によって RYR は核の内膜, 外膜両方に存在することが判明し $た^{10)}$. Xenopus oocyte から単離した核を用い てパッチクランプを行った実験でも $\mathrm{IP}_{3} \mathrm{R}$ のチャ ネル電流の直接記録が成功し，核の外膜に $\mathrm{IP}_{3} \mathrm{R}$ が存在していることが確認された ${ }^{11)}$.さらに, 核エンベロープや核内には phosphatidylinositol 4,5 , bisphophate $\left(\mathrm{PIP}_{2}\right)$ や PhospholipaseC $\beta 1$ 


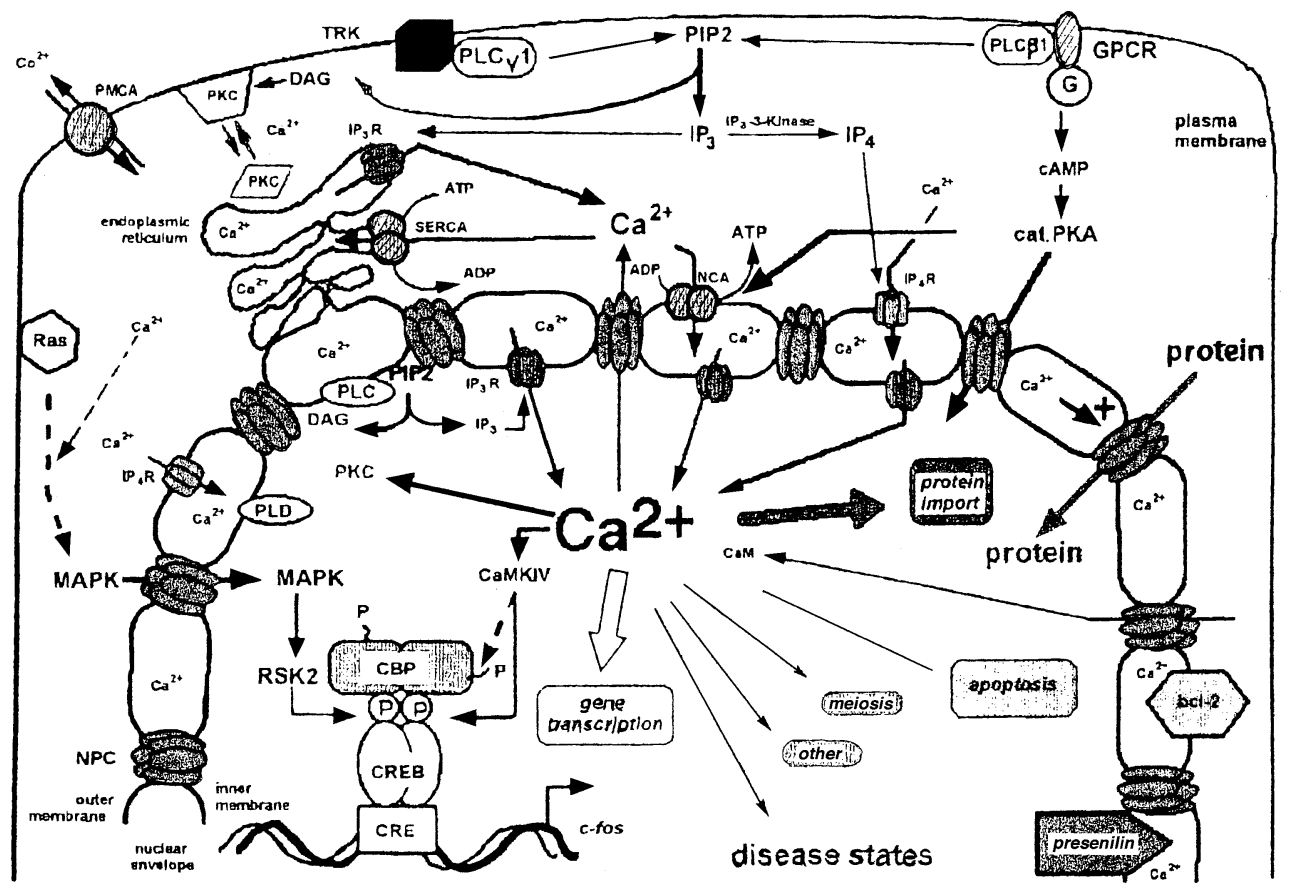

Fig. 2 Model for Calcium Signaling Pathways in the Cell Nucleus

$\mathrm{Ca}$ は核 Ca-ATPases や $\mathrm{IP}_{4} \mathrm{R}$ によって核エンベロープへ輸送され，そして核の内膜に存在する $\mathrm{IP}_{3} \mathrm{R}$ を介して， 核質へ遊離される。核質からの Ca の排除は核膜孔複合体 NPC を介して行われている. 核内における Ca に関連 する主な機能をイラストとして描いてある。(19)より引用.

NE : nuclear envelope, ER : endoplasmic reticulum, NPC : nuclear pore complex, PMCA : plasmamembrane-Ca ATPase, , SERCA : smooth endoplasmic reticulum CaATPase,NCA : Nuclear CaATPase , $\mathrm{IP}_{3} \mathrm{R}:$ 1,4,5-trisphosphate receptor, $\mathrm{IP}_{4} \mathrm{R}:$ 1,3,4,5-tetrakishosphate receptor, $\mathrm{RYR}$ : ryanodien receptor, $\mathrm{IP}_{3}:$ 1,4,5-trisphosphate, $\mathrm{IP}_{4}$ : inositol 1,3,4,5-tetrakisphosphate, $\mathrm{PIP}_{2}$ : inositol 4,5-bisphosphate, cADP ribose : cyclic adnosine diphosphate ribose, PLC $\gamma$ : phospholipase $\mathrm{C} \gamma$, PLC $\beta_{1}$ : phospholipase $\beta_{1}$, PLD : phospholipase D, CaM : Calmodulin, CDK : cyclin-dependent kinase, CaMK : $\mathrm{Ca}^{2+}$ Calmodulin-depednent protein kinase, CREB : CRE-binding protein, $\mathrm{PKC}$ : protein kinase C, DAC : Diacylglycerol, GPCR : G-protein coupled receptor, G: GTP-binding protein, Cat. PKA : catalytic subunit protein kinase A

が存在することが分っている ${ }^{22)}$. 細胞質内では PhospholipaseC $\beta 1$ は $\mathrm{PIP}_{2}$ を水解して $\mathrm{IP}_{3}$ と Diacylglycerol を作ることが良く知られている が, このように，セカンドメッセンジャーを作り 出す機構が核内部に存在するということは，核内 でも細胞質と同様または類似のメッセンジャーが 作られている可能性を示唆する.これらのことは, 核内シグナルによって Ca が核内へ供給される独 立した機構が核エンベロープに存在することを強 く支持すると考えられる.

\section{2 細胞質亡核内間の $\mathrm{Ca}$ 濃度差}

核内 $\mathrm{Ca}$ 制御機構を指示するもう 1 つの強力な 事実は細胞質と核内では $\mathrm{Ca}$ の濃度が異なること が挙げられる。もし，従来の説の “NPC を介す る自由な無制限な拡散”が正しいならば, 細胞質 と核内の $\mathrm{Ca}$ 濃度は常に平衡であるはずである. しかし, 細胞質と核内の $\mathrm{Ca}$ 濃度を検討した結果, 画者は同一でなく濃度に差があることが観察され ている. 特に細胞を刺激した時に両者間の濃度差 は著明になると報告されている，電気生理学的研 究からは, 既に, 1963 年に Loewenstein と Kan- 
no ${ }^{13)}$ が核エンベロープを介して, 細胞質と核内 にはイオンの濃度差があることを示しており，こ れは両者間で無制限に Ca が拡散するという考え 万に対する確固たる反論になるといえる。Ca 濃 度の計测には Ca-sensitive fluorescent indicators を用いた通常の顕微鏡および共焦点顕微鏡 が広く用いられ, 細胞質の $\mathrm{Ca}$ 濃度に関してはほ ぼ研究者の間で見解は一致しているが，核内 $\mathrm{Ca}$ 濃度に関しては未だ正確な濃度は分っていない。 研究者により核一細胞質間の $\mathrm{Ca}$ 濃度差は高かっ たり，低かったり，同じだったりと報告はまちま ちである ${ }^{14 \sim 16)}$ 。これらの結果が一致しない理 由として, 用いている細胞のシステムや計測方法 が異なったり，生理的条件が異なる為などが考え られている．また蛍光色素による標識では色素の 反応が核内と細胞質内では異なる可能性, 細胞内 の複雑なコンパートメント, Ca 結合蛋白の相違 等多くの問題があると思われる.

\subsection{Ca ストアーとしての核エンベロープ}

現在では, 核エンベロープは小胞体と同様に Ca ストアーであり, かつ核内腔を細胞質から隔 離するバリアの役割を果たしていることが広く支 持されるようになってきたが，ER と核エンベ ロープの内腔が構造的によ゙のように連絡している のか，それとも仕切りで隔絶されているのかは全 く分っていなかった. ごく最近の Subramanian と Meyer ${ }^{17)}$ の研究はこの疑問を解決し，さらに 核エンベロープの重要な役割を明らかにした。彼 らは分子生物学的手法を用いて, 動物細胞に elastase green fluorescent protein (EI-GFP) 融合蛋白を特異的に ER と核エンベロープの内 腔に発現させ，核エンベロープと ER 間のつな がりと $\mathrm{Ca}$ ストアーのトポロジィーの違いを共焦 点顕微鏡で検討した. その結果, 静止時の細胞で は $\mathrm{ER}$ 全体のネットワークと核エンベロープ内 腔は管腔状に連絡する構造を形成しており, そこ では約 $60 \mathrm{kD}$ の EI-GFP は自由に拡散し，また 管腔内の $\mathrm{Ca}$ 濃度は細胞全体で容易に平衡になる ことが明らかにされた。ささらに, ER は細胞質の $\mathrm{Ca}$ 濃度によりその構造が変化することがはじめ
て示された。細胞質の $\mathrm{Ca}$ 濃度を長時間（10 分 以上）上昇させると EI-GFP の拡散は著明に抑 制され，管腔状に繫がっていた ER は個々の Vesicle 状に分画化した. しかも，この ERの構 造変化は $\mathrm{Ca}$ 濃度を減少させると再び管腔状の連 絡を有する元の構造に戻る可逆的変化であった. ところが，ER と異なって，核エンベロープの方 は細胞質の Ca を上昇させても EI-GFP の拡散 は保たれ，その構造も特に影響を受けないことが 示された. しかし,このような ER の構造変化 は一過性 $\mathrm{Ca}$ 上昇や低頻度刺激による $\mathrm{Ca}$ スパイ クでは起こらないことから, 通常の条件下では $\mathrm{ER}$ と核エンベロープ内の $\mathrm{Ca}$ 濃度は細胞全体で ほぼ等しいと推測される.

Meyer らのグループは, 細胞質と核内腔それ ぞれに特異的に発現する蛍光標識のプローブの開 発をし ${ }^{18)}$ ，これを用いて，細胞質と核内間の巨 大分子の移動を検討した。これらの蛋白質のサイ ズは約 $70 \mathrm{kD}$ であるが, 細胞質の $\mathrm{Ca}$ 濃度を上 昇させたとき，細胞質に発現させた標識蛋白質は 核内へ移動せず，かつ，核内に発現させた標識蛋 白質も核外へ移動することなく核内に留まってい ることが確認された。このように核エンベロープ は細胞質と核のバリアーとして機能しており,こ れは細胞質内 $\mathrm{Ca}$ 濃度が上昇しても，正常に働い ていることを示しているといえる.

\section{3. $4 \mathrm{Ca}$ ストアーの Ca 濃度}

核エンベロープ内の $\mathrm{Ca}$ 濃度は, 膵臓の acinar cellsで Ca-sensitive dyes を用いた検討による と静止時には大体 100 300 uM くらいであると 推測されている ${ }^{19)}$. Petersen らによると, アセ チルコリン $(\mathrm{Ach})$ による刺激によりストアーの $\mathrm{Ca}$ は速やかに減少し, Achを除去すると, 再び $\mathrm{Ca}$ の取りこみが始まることを示した.この $\mathrm{Ca}$ の再取りこみの速度はストアーの $\mathrm{Ca}$ の濃度に依 存しており, $\mathrm{Ca}$ 濃度が上昇すれば, $\mathrm{Ca}^{2+}$ の取り こみ速度は減少し, negative feedbackにより核 エンベロープの $\mathrm{Ca}$ 濃度は調節されているとして いる ${ }^{19)}$.

一方，ユニークな新しい分子生物学的手法を用 
A

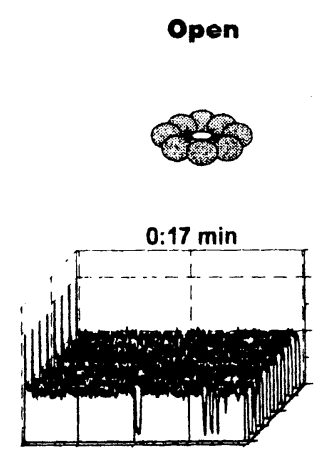

B
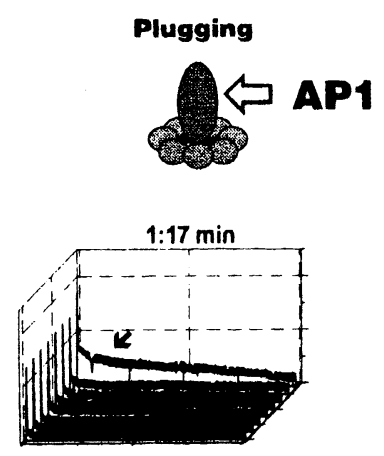

C

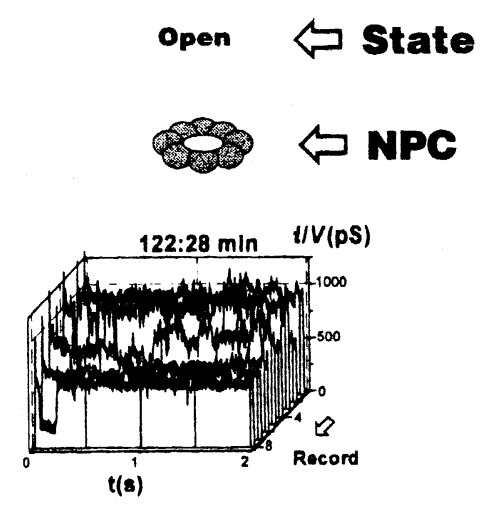

Fig. 3 Translocation of Natural Nuclear Protein Restricts Ion Flow. Recording by Path Clamp. (A-C) の各々，下段がチャネル記録，上段が NPC のスキーム，A), 単一NPC イオンチャネルの開閉. B), 活性 化蛋白質 : AP1 (c-Jun, $40 \mathrm{kD}$ ) が NPC を通過中で, 孔を塞いで，イオン電流はブロックされている. C), 蛋白 質が通過後再びチャネルの開口が見られる. (24) より引用)

いて開発された $\mathrm{Ca}$ の蛍光標識である“カメレオ ン (cameleons)”を用いた検討では小胞体の Ca 濃度は静止時では 60〜400 uM，そして刺激によ り小胞体から Ca が放出されたときには 1〜50 $\mathrm{uM}$ になると推測している ${ }^{20)}$. 新しい $\mathrm{Ca}$ の蛍 光標識カメレオンは青または藍色光変異型の緑色 蛍光蛋白質 (GFP), カルモジュリン, カルモ ジュリン結合ペプチド M13, そして, 緑色または 黄色光型の GFP が縦列配置した構造を持ってい る.これに Ca が結合するとカルモジュリンは M13 ドメインに巻き付き, 構造変化し, 側に位 置する GFP 間の蛍光共鳴エネルギー (FRET) を増大させる. カメレオンを核内や小胞体等の目 的とするオルガネラの特定部位に発現させ, また カルモジュリンを変異させて Caの親和性を調整 することにより, オルガネラの局所の $\mathrm{Ca}^{2+}$ 濃度 を測定することができる，実際には $10^{-8} \mathrm{M}$ から $10^{-2} \mathrm{M}$ 範囲で $\mathrm{Ca}^{2+}$ 濃度の測定を可能にした. このカメレオンの応用は, 核やオルガネラの限局 した部位の Ca シグナルの研究の発展に大いに貢 献すると期待されている.

核の外膜には $\mathrm{Ca}$ ポンプ ( $\mathrm{NCA})$ が存在するこ とが確認されているが5 7), 恐らくこのNCA が 細胞質の $\mathrm{Ca}^{2+}$ を核エンベロープ内へ取り込んで
いると思われる. NCA は ER の Ca ポンプとは 薬理学的性質に多少違いが認められるが, cAMP 依存性燐酸化によって活性化される.もう 1 つの 経路として，核の Ca の取り込みに inositol 1,3, 4,5-tetrakisphosphate $\left(\mathrm{IP}_{4}\right)$ が関与する経路が あると報告されている ${ }^{21)}$ 。核の $\mathrm{IP}_{4}$ 受容体は 74 $\mathrm{kD}$ の蛋白質で, これは今までに報告された他の $\mathrm{IP}_{4}$ 受容体と全く異なるものであり,この機能に ついてもまた $\mathrm{IP}_{4}$ の細胞質での役割についても いまだ良く分かっていない。

\section{NPC の機能調節と核膜}

細胞質と核内間の物質輸送は核膜孔複合体 (NPC) を介して分子が自由に行き来するという 考えに対する反論は以前からあった。例えば，あ る種のイオンや分子は核内之細胞質ではその分布 が異なることが知られていた ${ }^{22)}$. 最近の研究で はNPC は単なる孔ではなく, 孔の機能的構造が 核エンベロープによって調節されていることが 分ってきた. Xenopus Laevis oocytes から単離 したNucleus を用いた検討で, Ins $(1,4,5) \mathrm{P}_{3}$ 投 与, 低濃度の $\mathrm{Ca}$ 液への暴露または BAPTAを 用いる等の方法で核の $\mathrm{Ca}$ ストアーを枯渇させる 
A- $a$

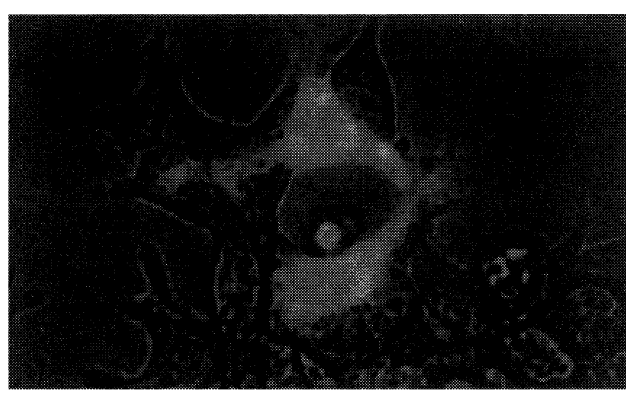

B - a

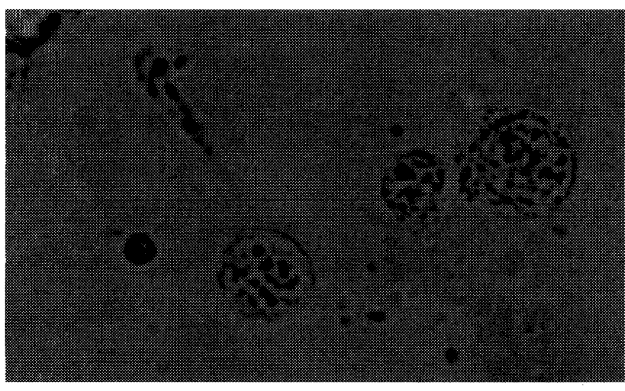

$A-b$

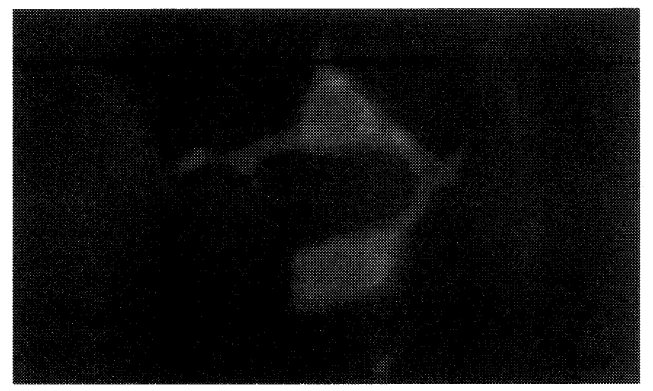

B - b

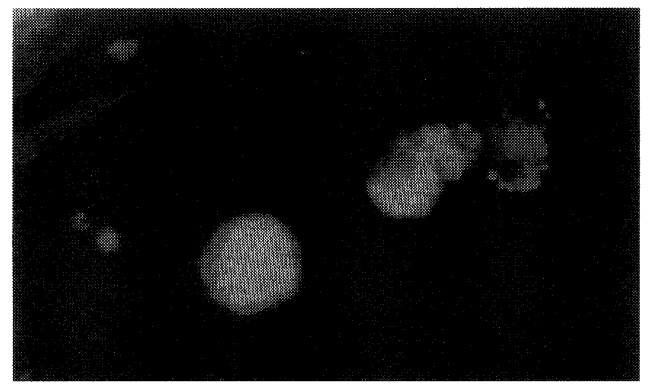

Fig. 4 HEK Cells Transfected GFP into ER and NE.

東京大学御子柴研究室の古市貞一助教授との共同研究で $\mathrm{ER}$ を特異的に蛍光標識して顕微鏡下で観察できるよう な GFP 融合蛋白質を作製し, HEK293 細胞に発現させた.この蛋白質は GFP 部分がER内腔に位置した膜貫通 トポロジーをとる.

$\mathrm{A}$, 同一標本の顕微鏡像で, $\mathrm{a}$ は光顕と蛍光像の重ねたもの, $\mathrm{b}$ は蛍光像を示す. 細胞内膜系が蛍光染色されてい るのが解る.

$\mathrm{B}, \mathrm{HEK} 293$ 細胞から核と ER を単離し顕微鏡下で観察した. a は光顕像， b は蛍光像. 蛍光染色された ER と核 エンベロープを認める.（著者未発表データー）

と, NPC の中央の孔がプラグされてしまうこと が原子間力顕微鏡 (Atomic force microscopy) および電子顕微鏡で明確に示された ${ }^{23}$ )。このよ うな NPC の構造変化は, ある程度の大きさの分 子が通過するのをブロックしたり，または受動的 拡散を中止させたりすると考えられる. 従って, NPC のイオンや分子に対する透過性は Ca スト アーすなわち, ER と核エンベロープの $\mathrm{Ca}$ の枯 渇レベルによって調節されているともいえる.

一方，パッチクランプ法を用いて核の NPC の 機能を検討した結果では, NPC は単なる孔では なくチャネルとしての開口, 閉口状態を呈するこ とが解ってきた ${ }^{24)}$. そして, 巨大分子が通過す るときはNPCの孔が塞がれて, チャネルのコン
ダクタンスは低下し, 通過後はもとのコンダクタ ンスに戻ることが示された (Fig. 3). 同様のパッ チクランプ法で核内と細胞質との分子の移動を検 討した結果, 細胞質の蛋白質で遺伝子の発現に重 要な役割を果たしている Transcription factors (TFs) である c-Jun (40 kD), NF-kB (50 kD), そして SP1 (100 kD) が核孔を通過するのが記録 された.これらのトランスロケーションは ATP なしでは数時間〜数十時間要するが, $2 \mathrm{mM} \mathrm{ATP}$ を加えると著明に加速され約 5 分以内で終了し た.この他にも同様の方法で， mRNA が核の $\mathrm{NPC}$ を介して排出されることも示されている. これらの事実はNPC の核内と細胞質間の輸送シ ステムとしての機能は, 細胞質または核内, 核工 
ンベロープにより調節されていることを示唆し, 今後, その詳細な調節機構の解明が待たれる.

\section{5.イオンチャネル電流による検討}

現在, 核の Ca のシグナル系の研究は Ca-sensitive dye や GFP などの Ca indicator を介し て，Ca の動態を観察するのが主流であるが，詳 細な機構の解明には $\mathrm{Ca}$ の動態を担っているイオ ンチャネルやトランスポーターの 1 分子の機能を 直接測定して検討する必要があると思われる. 細 胞膜や小胞体の種々の $\mathrm{Ca}$ チャネルに関しては パッチクランプ法や人工膜再構成法により単一 チャネル電流記録による研究が進んでいる. しか し, 核膜の $\mathrm{Ca}$ シグナルを単一チャネルレベルで 検討したものは未だ数少ない. 核膜にイオンチャ ネルの存在を初めて証明したのは, Mazzanti ら 25)であり，単離したねずみの前核にパッチク ランプ法を適応し, 最大 $200 \mathrm{pS}$ の K チャネルの 存在を示したのが最初である. その後ラットの肝 細胞から単離した核に $\mathrm{Cl}$ チャネルが存在するこ $と^{26)}$, 膵臓の acinar cell から単離した核の外 膜に Ca-acitivated $\mathrm{K}$ チャネル27), 単離した Xenopus oocyte nucleus に $\mathrm{IP}_{3}$ 受容体の単一 チャネルが記録された ${ }^{11 ， 28)}$. 生理的な膜上で, これらのチャネル機能を検討することは核膜の機 能を理解する上で重要であると思われ, 今後の研 究の発展が期待される. しかし, 実際の実験にお いて，顕微鏡下で特定のオルガネラ膜を識別する のは技術的に困難が多い. 我々は, この困難を克 服するために, GFP を ER 膜や核エンベロープ に特異的に発現させ, 蛍光識別しつつパッチクラ ンプする系の確立を現在試みている. 未だ, 開発 途中であるが, ER および核エンベロープの内膜 に特異的に発現する GFP 融合蛋白を HEK293 細胞に発現させ, 蛍光顕微鏡下で観察した (Fig. 4A).これらの細胞から核を低浸透圧液に暴露さ せて, 単離し, 核膜に発現している蛍光発色を指 標にパッチクランプで核膜上のイオンチャネルの 動態や調節機構を直接検討できるものと考えて, 現在研究を進めている (Fig. 4B).

\section{文献}

1) Berridge, M. J., Neuronal calcium Signaling (Review) Neuron $21:$ 13-26, 1998.

2) Berridge, M. J. Inositol trisphosphate and calcium signalling. (Review) Nature 361 : 315-325, 1993.

3) Intracellular compartments and protein sorting. in Molecular biology of the cell ed by B. Alverts, D. Bray, J. Lewis, M. Raff, K. Rboerts, JD. Watson, 1994.

4) Pante N., Abei U. Towoards understanding three-dimensional sturucture of the nuclear pore complex at the molecular level. Curr. Opin. Struct. Biol, 4 : 299-338, 1994

5) Kulikova, O. G., Savostyanov, G. A., Belyavtseva, L. M. Razumovskaya, NI. Study of ATPase activity and ATP-dependent accumulation of ${ }^{45} \mathrm{Ca}^{2+}$ in skeletal muscle nuclei : effects of denervation and electrical stimualtion. Biokhima 47 : 1216-1221, 1982.

6) Nicotera, P., McConkey, DJ., Jones DP Orrenius S. ATP atimulates $\mathrm{Ca}^{2+}$ uptake and increases the free $\mathrm{Ca}^{2+}$ concentration in isolated rat lever nuclei. Proc. Natl. Acad. Sci. USA 86 : 453-457, 1989

7) Humbert, JP., Matter N., Artault JC., Koppler P. Malviya, AN. Inositol 1,4,5-trisphosphate receptor is located to the inner nuclear membrane vindicating regulation of nuclear calcium signaling by inositol 1,4,5-trisphosphate. J. Biol. Chem. 271 : 478-485, 1996.

8) Malviya, AN., Rogue, P. Vincendon G. Stereospecific inositol $1,4,5-\left[{ }^{32} \mathrm{P}\right]$ trisphosphate receptor-mediated calcium release from the nucleus. Proc. Natl. Acad. Sci. USA 87 : 92709274, 1990

9) Gerasimenko OV., Gerasimenko JV., Tepikin AV., Petersen OH. ATP-dependent accumulation and inositol trisphosphate or cyclic ADP-ribose-mediated release of $\mathrm{Ca}^{2+}$ from the nuclear envelope. Cell $80: 439-444,1995$

10) Santella, L. Kyozuka, K. Effects of 1-methyladenine on nuclear $\mathrm{Ca}^{2+}$ transients and meiosis resumption in sstarfish oocytes are mimicked by the nuclear injection of inositol 1,4,5trisphosphate and cADP-ribose. Cell Calcium, 22 : 11-20, 1997 
11) Mark, DO., Foskette, JK. Sngle-channel inositol 1,4,5-trishphosphate receptor currents revealed by patch clamp of isolated xenopus oocyte nuclei. J. Biol. Cham, 269 : 29375-29378, 1994

12) Divecha, N., Banfic H., Irvine RF. Inositides and the nucleus and inositides in the nucleus. Cell 74 : 405-407, 1991

13) Loewenstein, WR. Kanno, Y. The electrical conductance and potential across the membrane of some cell nuclei. J. Cell. Biol. 16 : 421-425, 1963

14) Brini, M. Murgia, M. Pasti, L. Picard, D., Pozzan, T. Rizzuto, R. Muclear $\mathrm{Ca}^{2+}$ concentration measured with specifically targeted $\mathrm{re}^{-}$ combinat aequorin. EMBO J. 12 : 4813-4819, 1993.

15) Himpens, B., Smedt, H. Casteels, R. Relationship between $\left[\mathrm{Ca}^{2+}\right]$ changes in nucleus and cytosol. Cell Calcium 16 : 239-246, 1994.

16) Badminton, MN., Campbell, AK., Bolsover SR. Differential regulation of nuclear and $\mathrm{cy}^{-}$ tosolic $\mathrm{Ca}^{2+}$ in Hela cells. J. Biol. Chem. 271 : 31210-31214, 1996.

17) Subramanian, K., Meyer, T. Calcium-induced restructuring of nuclear envelope and endoplasmic reticulum calcium stores. Cell 89 : 963-971, 1997.

18) Albritton, NL. Oancea, E. Kuhn, M. Meyer, T. Source of nuclear calcium singals. Proc. Natl. Aca. Sci. USA, 91 : 12458-12462, 1994

19) Malviya AN., Rogue PJ. "Tell me where is calcium bred" : clarifying the roles of nuclear calcium. (Review) Cell, $92:$ 17-23, 1998.

20) Miyawaki, A., Lllopis J., Heim R., McCaffery
JM., Adams JA., Ikura M., Tsien RY. Fluorescent indicators for $\mathrm{Ca}^{2+}$ based on green fluorescent proteins and calmodulin. Nature, 388 : 882-887, 1997

21) Koppler P., Matter N., Malviya AN. Evidence for stereospecific inositol 1,3,4,5-[3H]tetrakisphosphate binding sites on rat liver nuclei. J. Biol. Chem. 268 : 26248-26252, 1993.

22) Paine, P. L., and S., B., Horowiz, The movement of matereal between nucleus and cytoplasm. Cell Biol. 4 : 299-338, 1980.

23) Perez-Terzic C., Pyle, Jaconi, JM., StehonoBittel, L., Clapham, DE., Conformational States of the nuclear pore Compex induced by Depletion of Nuclear $\mathrm{Ca}^{2+}$ Stores. Science 273 : 1875-1877, 1996

24) J. O. Bustamante, J. A. Hanover, A. Liepins, The Ion Channel Bihavior of the Nuclear Pore Complex. J. Membrane Biol. 146 : 239-251, 1995

25) Mazzanti M, DeFelice LJ., Cohn . J., Malter $\mathrm{H}$. Ion channels in the nuclear envelope. $\mathrm{Na}$ ture 343 : 764-767, 1990

26) Tabares L. Mazzanti M. Clapham DE. Chloride channels in the nuclear membrane. Journal of Membrane Biology. 123 (1) : 49-54, 1991 Jul.

27) Maruyama Y., Shimada H., Taniguchi J. $\mathrm{Ca}^{2+}$-activated cahnnels in the nuclear envelope isolated from single acinar cells. Pflugers Archiv European Journal of Physiology. 430 : 148-150, 1995

28) Stehno-Bittel L., Luckhoff A., Clapham DE., Calcium release from the nucleus by InsP3 receptor channels. Neuron 14 : 163-167, 1995 （受付 1998 年 11 月 3 日 掲載決定 11 月 18 日） 